\title{
Nation-Level Gender Inequality and Couples' Income Arrangements
}

\author{
Joanna R. Pepin, $\mathrm{PhD}$ \\ jpepin@buffalo.edu \\ Department of Sociology \\ University at Buffalo \\ ORCID: 0000-0002-3134-2121 \\ Philip N. Cohen, $\mathrm{PhD}$ \\ pnc@umd.edu \\ Department of Sociology \\ University of Maryland \\ ORCID: 0000-0003-2839-3144
}

\begin{abstract}
Using data from the 2012 International Social Survey Program $(n=8,269)$, this study investigated how couples integrate and manage their income across 20 countries with varying degrees of gender inequality. Couples were more likely to report that one person managed the shared pot of money in countries with high gender inequality compared with couples in more gender equal countries. This pattern was not moderated by within-couple earnings equality. We found a cohabitation - marriage gap in income arrangements that is largest where national-level gender equality is high. In more gender equal contexts, married couples were more likely to pool and manage their money together, whereas a larger proportion of married couples assigned one money manager in countries with less gender equality. Cohabiting couples were more likely to keep some money separate than to take-up a pooled, jointly managed approach in more gender equal countries. Findings demonstrate the need to consider both management and pooling dimensions of couples' treatment of money to understand the influence of contextual factors on couples' income arrangements.
\end{abstract}

Keywords: intrahousehold finances, gender inequality, marriage, cohabitation

Funding: We gratefully acknowledge support from the Eunice Kennedy Shriver National Institute of Child Health and Human Development grant, P2CHD041041, awarded to the Maryland Population Research Center and grants P2CHD042849, Population Research Center, and T32HD007081, Training Program in Population Studies, both awarded to the Population Research Center at The University of Texas at Austin. The content is solely the authors and does not necessarily represent the official views of the National Institutes of Health.

Acknowledgments: An earlier version of this paper was presented at the 2016 annual meeting of the American Sociological Association in Seattle, Washington.

Conflict of Interest: The authors declare that they have no conflict of interest.

Ethical approval: This article does not contain any studies with human participants performed by any of the authors.

Data repository: Data and code for the paper analyses are available at: https://github.com/jrpepin/ISSP_Income-Pooling 


\section{Introduction}

A multi-dimensional approach to understanding couples' income arrangements, classified by couples' integration as well as management of income, is important to understanding crossnational variation in the gender revolution and family dynamics (Altintas and Sullivan 2016; Goldscheider et al. 2015). Existing research tends to emphasize integration differences between cohabiting and married couples', termed the "cohabitation—marriage gap" (Hamplová et al. 2014; Hamplová and Le Bourdais 2009; Hiekel et al. 2014; Präg et al. 2019); or attend to variation in the management of money among married couples (Lauer and Yodanis 2011; Yodanis and Lauer 2007a, 2007b). As the nature of marriage has changed, and cohabitation has risen to complement or replace marriage in many societies, the role of couples' income arrangements with regard to gender inequality remains unsettled (Lauer and Yodanis 2010; Steuber and Paik 2014; Yodanis and Lauer, 2014). The integration and management components of income arrangements may be gender egalitarian or inegalitarian, depending on couples' partnership status, and the underlying power balance within the couple and in the wider society (Hu, 2019; Ludwig-Mayerhofer et al. 2011; Tichenor 1999; Treas 1993; Vogler 1998; Vogler \& Pahl 1994).

Using data on 20 countries from the 2012 International Social Survey Program (ISSP) module on changing family and gender roles, we evaluate how cohabiters' and spouses' income

arrangements, accounting for issues of both access to and control over money, are influenced by women's standing at the couple level and societal level. This study advances prior research on relationship dynamics and gender inequality in two ways. First, we consider women's standing in society at the couple level and national level to better understand the context for couples' treatment of income. Comparative research is especially suited for answering questions of how 
cultural context, in this case country-level gender inequality, moderates family level associations (Yu 2015). Second, we address both management and integration dimensions of couples' income arrangements, which may yield new insights into how couples reconcile tensions between the family domain's emphasis on interdependence and the market domain's emphasis on selfreliance (Bellah et al. 2008; Yodanis and Lauer 2014). We disaggregate our findings by couples' partnership status to consider how these tensions may be resolved differently for married spouses compared with cohabiting couples.

\section{Couples' Income Management and Integration}

Couples' income arrangements are shaped by women's participation in the labor market (Hobson 1990; Präg et al. 2019), and by institutional and cultural forces which vary widely between countries (Roman and Vogler 1999; Yodanis and Lauer 2007a, 2007b). Women’s earnings may translate into more economic control, but only in contexts of gender equality at the societal level. For instance, the likelihood one spouse manages all financial resources is lower where male-breadwinner ideology is less prevalent at the country level (Yodanis and Lauer 2007a, 2007b). In countries with high male unemployment, the prevalence of couples with women as primary-earners is high, but women's greater earnings are not associated with women's empowerment (Vitali and Arpino, 2016). Thus, we hypothesize that more economically equal couples - that is, couples with earnings that are relatively similar-would be more likely to report equally managing their money than couples with larger disparities between their earnings.

Evidence also suggests, however, that in national contexts of shared family earnings, the effects of spouses' relative income on couples' treatment of money diminishes (Yodanis and Lauer 2007b). These findings reinforce the importance of considering women's standing at the couple level as well as the societal level, as there may be important differences in the meaning 
and impact of women's financial contribution to their families. Simply having relatively equal earnings may not necessarily lead to more equal management of income, as the latter but may be contingent on the societal environment. Thus, couples' earnings equality may be associated with equal management of income only in highly unequal gender contexts.

With regard to integration of income, in societies where cohabitation is prevalent and institutionalized, one might expect cohabiting couples to treat their financial resources similarly to the way married couples do, pooling their finances instead of keeping economic resources separately. Yet, existing research shows that married couples are more likely than cohabitors to pool money into a shared family pot across various contexts (Hamplová et al. 2014; Hamplová and Le Bourdais 2009; Heimdal and Houseknecht 2003; Hiekel et al. 2014; Kenney 2004, 2006; Lyngstad et al. 2011; Vogler et al. 2006). Across welfare regimes, cohabiting couples tend to keep their money separate more often than married couples (Hamplová and Le Bourdais 2009; Präg et al. 2019). Some countries, such as Norway, have shifted tax policies and social security systems towards treating cohabitors more like married couples (Noack 2001), but even there distinctions remain, as Norwegian cohabiting couples do not have a legal duty to provide for one another in the same way married couples do (Lyngstad et al. 2011). The nearly universal tendency of cohabiting couples to exhibit lower levels of financial integration is surprising given the disparate trends in cohabitation.

Cohabiting couples tend to emphasize equal contributions to joint accounts and shun financial dependence (Bennett 2013; Elizabeth 2001). In gender unequal contexts there are two distinct theoretical predictions for cohabiting couples. On one hand, couples who remain unwed in gender unequal societies may be a select group highly committed to gender equality, despite lacking legal protection. Thus, we might expect to see a greater difference in the proportion of 
married and cohabiting couples who keep some or all money separate in contexts of high gender inequality compared with couples in societies with less gender inequality. On the other hand, couples who cohabit in gender unequal societies may organize their finances more similarly to their married counterparts, emulating marriage in order to gain the benefits of security or conformity not automatically available to cohabiting couples. Thus, couples in highly gender unequal societies may be as likely as married couples to pool financial resources, even if a greater proportion of cohabitors report equal management of their income than married couples.

This study uses the Gender Inequality Index (GII), a measurement of gender disparity developed by the United Nations Development Programme, to mitigate some of these concerns. The GII provides a comprehensive measurement of the cultural context that may moderate family-level practices. It measures three aspects of gender inequality: reproductive health, measured by the maternal mortality ratio and adolescent birth rates; empowerment, measured as the proportion of women who occupy parliamentary seats and the proportion of women to men aged 25 years and older with some secondary education; and economic status, measured as the female labor force participation rate (Gaye et al. 2010). Thus, the GII measures a set of countrylevel factors expected to influence gendered behavior at the couple level. Because the goal of this study is not to identify country level mechanisms, but rather the role of the gendered cultural context overall, the assumption of joint significance of multiple dimensions of inequality is advantageous.

We evaluate whether couples' earnings equality and partnership status are associated with income arrangements across these contexts. Due to the complexity of cross-national differences, with many possible variables of interest, and a limited number of countries to study, we adopt a descriptive approach to this analysis, and use multivariate models to isolate 
relationships rather than testing causal hypotheses. Nevertheless, we used the varied prior findings related to women's standing at the couple and societal level and couples' income arrangements, reviewed above, to delineate four theoretical predictions regarding married and cohabiting couples' integration and management of income: Hypothesis 1 - there is a positive association between couples' earnings equality and equal management of money across contexts; Hypothesis 2- nation-level gender inequality has a moderating effect on the relationship between couples' earnings equality and equal management of income; Hypothesis 3 - the cohabitation - marriage gap in income arrangements will be larger in contexts of high gender inequality compared with contexts with less gender inequality; Hypothesis 4- the cohabitation —-marriage gap in income arrangements, specifically along the integration dimension of income integration, will be smaller in contexts of high gender inequality compared with contexts with less gender inequality.

\section{Methods}

\section{Data and Sample}

We use data from the 2012 International Social Survey Program (ISSP) module on changing family and gender roles (ISSP Research Group, 2012). Because our goal is to assess the degree to which variation in couple-level and nation-level indicators helps explain crossnational variation in the marriage/cohabitation gap, rather than to document up-to-date statistics about the size of the marriage/cohabitation gap, the 2012 ISSP remains the best available dataset for these nation-level comparisons even though the prevalence of these factors may have changed in the last decade. Although the sampling procedures differ by country, a methodology committee works to ensure the data is representative of those 18 years old and older to facilitate cross-national comparisons. 
The dataset contains information from 36 countries, although we start with 29 countries that differentiate between a legal marital status and living with a steady partner and then further limit the sample to those that have at least 30 cohabitors prior to sample restrictions being imposed, leaving 22 countries. Finally, we excluded Canada due to reported data inconsistencies in the original dataset (per the codebook) and South Africa because there was no data collected on attitudes about satisfaction with family life, an important influence on money organization (Addo and Sassler 2010). The resulting sample contains 20 countries: Argentina, Australia, Chile, Czech Republic, Finland, France, Germany, Iceland, India, Ireland, Latvia, Lithuania, Norway, Philippines, Poland, Spain, Sweden, Switzerland, Unites States, and Venezuela $(N=$ 18,122 married or cohabiting individuals). Due to national differences in retirement practices and to reduce the influence of unmeasured effects on money arrangements related to later life stages such as disability and financial support to aging parents, we restricted the sample to respondents between 18 and 54 years old $(\mathrm{N}=11,377)$. The total analytic sample contains 8,269 respondents with complete data. The average sample size per country was 413 respondents, ranging from 231 people in Argentina to 917 people in Spain.

\section{Dependent Variable}

The dependent variable, couples' income arrangements, was adapted from the following survey question: "How do you and your spouse/partner organize the income that one or both of you receive? Please choose the option that comes closest." The answer choices are as follows:

(A) I manage all and give my partner their share; (B) Partner manages all and gives me my share;

(C) We pool all money, each take out; (D) We pool some money, rest separate; (E) We each keep own money separate; (F) My son or my daughter-in-law manage the money; $(\mathrm{G})$ Don't know, refused; and $(\mathrm{H})$ No answer. Answer choices F-H were dropped because they were not of 
primary interest to this study, and represent less than $5 \%$ of the sample. We code the remaining five responses (A-E) into a four-category dependent variable labeled as follows:

1. One manager

(A) I manage all and give my partner their share

(B) Partner manages all and gives me my share

2. Manage together

(C) We pool all money, each take out

3. Pool some

(D) We pool some money, rest separate

4. Keep separate

(E) We each keep own money separate

In the first two answer responses, pooling all money is implied but not explicitly stated. Although it is potentially ambiguous, we interpreted (C) to mean joint management of pooled finances, as it is the response most likely chosen by those who most fully combine both accounts and management. We did not distinguish the gender of the person who solely manages the money in (A) and (B) because earlier research indicates that women are disadvantaged in onemanager families regardless of the gender of the managing partner (Nyman 1999; Roman and Vogler 1999; Vogler and Pahl 1994). In Appendix Table A, we present the distribution of the income organization arrangements by nation.

\section{Predictor Variables}

This study has three primary predictor variables of interest. First, to measure a country's level of gender inequality, we use the Gender Inequality Index (GII), from the Human Development Report by the United Nations Development Program (Gaye et al. 2010). We used 
the 2012 indices of the GII to correspond with the survey year of the ISSP data used in this analysis (Malik 2013). The higher the GII value the more disparities there are between women and men in a country. The GII in theory ranges from 0 to 1 , but the measured range in our data is from .06 (Switzerland and Sweden) to .61 (India). For interpretation, we multiply the scale by 100.

Second, the earnings equality variable represents the gender gap in total household income at the couple level. Due to data limitations and national differences in the sources of income for couples (Sani 2015), we rely on a general measure of couples' income disparity. Respondents were asked: “Considering all sources of income, between you and your spouse/ partner, who has the higher income?" Potential responses include: (1) My spouse/partner has no income; (2) I have a much higher income; (3) I have a higher income; (4) We have about the same income; (5) My spouse/partner has a higher income; (6) My spouse/partner has a much higher income and (7) I have no income. Combining sole income, much higher, and higher income, and using the respondents' gender, we arrive at the following categories: (1) man primary earner; (2) woman primary earner; and, (3) equal earners. Couples who report a solo earner may have qualitatively different dynamics of sharing income compared with dual-earners because they, by definition, pool resources. In Appendix Table B, we show the full model results with a reduced sample $(N=6,916)$, restricted to couples that report both partners have at least some income. These sensitivity results show the conclusions made in this paper remain largely the same.

Partnership status was the third independent variable of primary interest to this study. Couples were coded as married or cohabiting based on two survey questions. Respondents were coded as married if they reported their current legal marital status was married or they were in a 
civil partnership. Respondents were also asked: "Do you have a spouse or a steady partner and, if yes, do you share the same household?" If they answered "Yes, have partner; live in same household" but they were not married, they were coded as cohabiting. Table 1 shows the three key independent variables, country level gender inequality, average earnings equality, and partnership status.

\section{[Insert Table 1 about here.]}

Next, we detail the remaining independent variables that prior research suggests are associated with couples' income arrangements (Burgoyne and Morison 1997; Elizabeth 2001; Pahl 1990; Singh and Lindsay 1996; Vogler 2005; Vogler and Pahl 1993).

Female report. We include a dichotomous indicator for gender of the respondent to adjust for gender differences in perceptions.

Age. Age is a continuous variable ranging from 18 to 54. On average, younger people hold less traditional family values compared to people who are older (Bolzendahl and Myers 2004).

Parent. To address some selectivity issues between cohabitors and married couples, we consider presence of children an indicator of investment in the relationship (Barlow 2008; Kenney 2004; Präg et al. 2019). Respondents are coded as being a parent if they indicated they had any children under age 18 living in their household.

Employment. We use a categorical variable for respondents' primary employment status: full-time employment (35+ hours a week), part-time employment, unemployment, student, and not in the labor force.

Previous homemaker status. Respondents' current financial situation may reflect life course variation in work and family arrangements, so we include a dichotomous coded 1 if the 
respondent (if a woman) or the respondent's partner (if a man) previously worked part-time or stayed at home when a child was under school age. Respondents who worked full-time (if a woman) or whose partner worked full-time (if a man), non-parents, not applicable responses, and missing information for other reasons were all coded 0 .

Education. We include education as an indicator of social class. The ISSP provides seven standardized educational categories across countries: no formal education, primary school/elementary school, lower secondary, upper secondary, post secondary/non-tertiary, lower level tertiary/first stage, and upper level tertiary.

Housework. ISSP asked respondents the following question: "In your household who does the following things ...?" Items included laundry, repairs, groceries, cleaning, meals, and care work. Answers were reported on a six point scale: (1) Always me; (2) Usually me; (3) About equal or both together; (4) Usually my spouse/ partner; (5) Always my spouse/ partner; and (6) Is done by a third person. We combine "always me/always my spouse" and "usually me/usually my spouse" and paired the items with respondents' gender to create three levels per activity: female higher (coded 1); about equal or done by a third person (coded 2); and male higher (coded 3). We create an index representing average division of labor from the six labor activities (Cronbach's alpha $=.94$ ) and subtract six from the sum of the total responses to create an index ranging from 0 to 12 . A value of 6 indicates equality, and the average score in the sample is 4.13, which indicates divisions of housework that disadvantage women, on average.

Respondent's mother's work history. A dichotomous variable indicating whether the respondent's mother worked for at least one year after they were born and before they turned fourteen years old was also included because individuals whose mothers participate in the labor force tend to hold more gender-egalitarian beliefs (Ciabattari 2001; Davis and Robinson 1991). 
Happiness with family life. Respondents were asked "All things considered, how satisfied are you with your family life?” Answer choices are on a seven-point scale ranging from completely dissatisfied (coded 1) to completely satisfied (coded 7).

Table 2 presents descriptive statistics of all model predictors. [Insert Table 2 about here.]

\section{Analytical Strategy}

We use multinomial models because the outcome variable is categorical (one money manager, jointly manage pooled money, keep some money separate, and keep all money separate). First, we consider country level differences in organizational approaches and the Gender Inequality Index, before adding the earnings equality of the couple and then, in a separate model, couples' partnership status. Next, we add the individual characteristics found in previous research to be important for the organization of money. We then test whether country level gender inequality moderates individual level variations associated with earnings equality and partnership status.

To account for potential unobserved country-level factors that may lead to respondents within countries being more alike in their financial management strategies than they are with respondents from other countries, we implement Stata's cluster command in all multinomial analyses. As a sensitivity test, we also conduct a multilevel, multinomial analysis. The assumption in this model is that the individual level characteristics have constant effects, if any, across countries. The conclusions drawn from the multilevel model are similar to the models presented in the central text of this article. To ease interpretation of the results, we present the results from the multinomial analyses using the cluster adjustment and discuss figures 2 and 3 , which show the estimates from the regression-adjusted means. In other words, the figures show 
the predicted percentages selecting each organizational approach, holding the other model variables constant at their means. As an additional sensitivity test, we also repeated the models excluding each country independently to check for potential outliers. Excluding Finland and the Phillipines altered several significance tests, but in no case did the exclusion of one country change the overall findings.

\section{Results}

Figure 1 presents the proportion of all couples using each income organization approach at for each of the 20 countries in the sample. The countries are shown in order from the most gender unequal country (India) to the country with the most gender equality (Switzerland and Sweden). The proportion of respondents who reported they shared all money and one person managed it (One money manager) was greater in countries with high gender inequality than in countries with low gender inequality. For example, more than $50 \%$ of respondents in the Philippines and in Chile, countries with high gender inequality, reported one person managed all money. In contrast, respondents from the Nordic countries (Finland, Norway, Sweden, and Iceland) and France, countries with low scores on the Gender Inequality Index (GII), were the least likely to report one money manager. In Spain and Poland, about $70 \%$ of respondents reported they pooled all money and each took out what they needed (Manage money together), both countries with moderate scores on the GII. Reports of pooling some money and keeping the rest separate was most common in Norway, Sweden and Finland and least common in Chile and the Philippines. Keeping all money separate was highly unusual in the Philippines (about 1\%),

[Insert Figure 1 about here.]

Table 3 presents the relative risk ratios of each income arrangement. Model 1 shows the bivariate relationship of Gender Inequality Index (GII) to the income arrangements. Model 2 
adds couples' earnings equality, and in Model 3 we show the GII and partnership status coefficients. The coefficients for the GII show that effect size of the GII is considerable. In countries with high gender inequality, couples were more likely to designate one money manager compared with jointly managing money. The country level gender-inequality remained significant with the addition of the couple-level earnings equality and partnership status. Model 2 shows that when couples' earnings were equal, they were less likely to have one money manager than to report managing pooled money together. When women were the primary-earners, couples were more likely to keep some or all money separate than jointly manage shared money. As expected, Model 3 shows cohabitors were more likely than married couples to keep some or all of their money separate. Interestingly, cohabiting couples were also more likely than married couples to designate one person the money manager for all shared money rather than jointly manage pooled money. In general, the results were consistent with previous research findings and theoretical expectations that a greater proportion of married couples integrate their finances compared with cohabiting couples.

[Insert Table 3 about here.]

In Table 4, we added the remaining individual level predictor variables to the model. As seen in Model 4, the Gender Inequality Index (GII) remains a statistically significant predictor of the ways couples organize their earnings, even with the addition of the individual level control variables. Couples living in countries with high gender inequality were less likely to manage money together compared with any of the other income arrangements. These country level results are consistent with prior research showing the gender climate at the nation level influence micro-level dynamics in families. In the full model, consistent with Hypothesis 1, earnings equality remained associated with a decreased likelihood of having one money manager, 
compared with managing pooled money together. Women's primary-earner status no longer had a statistically significantly different effect than men's primary-earner status on income organizational arrangements with the addition of the other control variables. Partnership status remained strongly associated with how couples managed their money, even with the addition of the other control variables. Cohabitors were more likely than married couples to select a money organization arrangement other than managing pooled money together.

\section{[Add Table 4 about here.]}

We next turn to Model 5, which presents the interaction of the GII with the relative earnings of couples. For ease of interpretation, Figure 2 presents the predicted proportion with each income arrangement, holding all the other model variables constant at their means. High nation-level gender inequality was associated with a greater share of couples reporting one person managed all pooled money, regardless of the relative income configuration. Further, no matter the couple-level earnings equality, couples were more likely to say they jointly managed their pooled income in more gender equal countries than in countries with high gender inequality. Compared with economically homogamous couples, couples with unequal earnings were slightly less likely to keep all money separate in highly unequal countries, although this arrangement was the least frequent organizational system for all couples in every context. In more gender equal countries, the proportion of couples keeping all money separate did not vary by couple-level earnings equality. Still, there was little evidence that nation-level gender inequality had a moderating effect on the association between couples' economic equality and equal management of income, inconsistent with Hypothesis 2.

[Insert Figure 2 about here.] 
As shown in Model 6, the interaction between GII and partnership status was statistically significant for cohabiting couples withholding some or all money compared with jointly managing money. Figure 3 shows the predicted proportions of each income organization arrangement along the GII (using the upper and lower bounds of the GII for the countries in the sample), holding all other model variables constant at their means. For both married and cohabiting couples, as gender inequality decreased, the proportion of couples who said one person managed the money decreased. How the share of couples with this arrangement was replaced differed depending on the partnership status of the couples.

The predicted proportion of married couples withholding some or all money remained mostly the same across gender contexts. Instead, married couples were more likely to say they jointly managed their pooled money in less gender unequal contexts than in contexts of high gender inequality. In contrast, in the less unequal gender contexts, cohabitors were more than twice as likely as they were in the most unequal contexts to keep their money separate. The proportion of cohabiting couples sharing some but not all of the income was substantially greater in less gender unequal contexts than in high inequality countries. Thus, these results were inconsistent with Hypothesis 3, that the cohabitation-marriage gap in income arrangements would be larger in contexts of high gender inequality compared with contexts with more gender equality. The findings do not support the prediction that couples who remain unwed in gender unequal societies may be a select group highly committed to gender equality, as married and cohabiting couples alike reported one money manager of pooled income in highly unequal countries. In contrast, results were consistent with Hypothesis 4, that the cohabitation-marriage gap in income arrangements would be smaller in contexts of high gender inequality compared with contexts with less gender inequality. Specifically, cohabitors were less likely to integrate 
their income in less unequal countries than in high inequality contexts. These results suggest that the ways egalitarian ideals are translated into practice within households is dependent on partnership status.

[Insert Figure 3 about here.]

\section{Discussion}

We argue that cross-national research on money in families should consider how couples' financial organizational systems are jointly influenced by women's relative standing in society at the couple-level and national-level and by partnership status. Using data on 20 nations, we find the influence of the Gender Inequality Index on couples' income management was considerable, even after accounting for couple-level earnings equality, partnership status, and other individuallevel factors. The multinomial modeling showed a negative correlation between nation-level gender inequality and reporting one money manager. Regardless of couples' earnings equality, a larger proportion of couples reported that one person managed the shared pot of money in gender unequal countries compared with more gender equal countries. This was especially when men were the primary earner. Still, equal-earning and female-primary-earner couples had remarkably similar organizational arrangements as male-breadwinner families in both gender unequal and more gender equal countries.

Couples were most likely to report that they pooled their money and each took out what they needed in countries with greater gender equality, no matter their earnings equality. There was little to no difference in the proportion of couples who kept some or all money separate, regardless of the earnings equality of the couples or country level gender inequality. The results showed little evidence that couples most able to enact gender egalitarian relationships (e.g., equal-earners or women primary-earners) organized their finances differently than male- 
breadwinner couples, even in different gendered climates. Overall, we found little evidence that the interaction of women's standing in society at both the couple level and national level is a primary driver in how couples integrate their earnings.

Married couples continued to pool their money in more gender equal countries, but were more likely to report joint management instead of one money manager when country level gender inequality was low. Cohabiting couples were more likely to report they kept some or all of their income separate in contexts with less gender inequality, compared with cohabitors residing in contexts with greater gender inequality. In countries with greater gender inequality, cohabitors' income arrangements were more diverse than married couples. The results suggest that changing partnership patterns may be more influential to how money is allocated within families than are further gains in women's economic status at the individual level.

Counter to the suggestion that cohabiting couples in highly gender unequal countries may be a highly selective group especially committed to gender equality, married and cohabiting couples' financial arrangements were more similar in contexts of high gender inequality. It may be that in places with high gender inequality, cohabitation does not necessarily indicate greater equality than among married couples. Still, in more gender equal contexts, cohabiting couples were less likely to emulate married couples' financial systems. Marriage continues to be seen as a patriarchal institution, and the couples who forgo marriage in more gender equal societies may withhold money from the common pot under a logic of prioritizing equality through autonomy rather than equality through integration. These findings suggest that in contexts of greater gender equality, cohabitation is not simply be a weaker form of marriage but rather may be seen as an alternative family arrangement. Consistent with prior research, cohabitors and spouses may have 
distinct styles of income arrangements (Singh and Lindsay 1996), but this may be conditional on women's standing at the societal level.

This study is not without limitations. As with all cross-national research, the study design may be limited by omitting important variables, and by the limited number of countries we can include. Establishing generalizable links between macro-level influences and couple-level outcomes is challenging due to the difficulties operationalizing country-level variables (Lewis and Den Dulk 2008; Ollier-Malaterre et al. 2013). Studies of specific policy effects always carry the risk that other macro-level forces explain the identified nation level effects (Yu 2015). Further, comparative research always risks nonequivalence in measurement approaches across diverse contexts (Yu 2015). For example, pooling all money may mean one thing to respondents taking the survey in India and quite another to survey respondents in Germany. Although the use of the GII was purposefully selected to minimize some of the trouble with omitted nation level variables, the GII also suffers from measuring some forms of inequality at the expense of others (Permanyer 2013). Additional studies with other measurements of the gender climate of countries are important to fully understanding how changes in gender inequality at the macro level moderate family level outcomes.

It may be beneficial to further explore how other individual level characteristics, such as gender attitudes and relationship duration, interact with national variation in gender inequality. Although many countries asked respondents about their beliefs about working mothers (e.g., "A working mother can establish just as warm and secure a relationship with her children as a mother who does not work"), the survey in Spain did not. The survey in the United States only asked married respondents about their relationship duration, and in the Philippines they did not ask about relationship duration at all. In order to use the data from as many nations as possible, 
we decided to exclude these predictors. Analyses including relationship duration information and excluding respondents from the United States and Philippines do not change the conclusions presented in this paper (see Appendix Table C). It might also be beneficial to focus exclusively on dual-earner couples and further distinguish between types of income. In the US the survey did not record partners' employment status or work hours in cohabiting couples, and the codebook documented errors' in Spain's data on partners' employment. Therefore, we could not restrict the sample to employed couples. Additionally, teasing apart the influence of national differences in the sources of income for couples, such as paid family leave, may improve understating of the ways gender dynamics influence income organization (Sani 2015).

Future empirical work is needed for understanding how changes in the family intersect with the larger context of changing gender norms. It is possible that the legal regulation of marriage makes pooling all resources in high egalitarian countries less risky for married couples, while cohabitors keep some money separate as a way to protect women's interests. It remains unclear if couples living in countries with a strong commitment to gender equality only adopted the rhetoric of equal sharing without practicing equal money arrangements. It is possible that couples who marry in more egalitarian countries may incorporate rhetoric of equal sharing even as the organization of money fails to live up to those expressions of equality (Addo and Sassler 2010; Bisdee et al. 2013; Burgoyne 1990; Burgoyne and Lewis 1994; Burgoyne and Morison 1997; Kenney 2006). Although we do not have detailed measures of financial decision making, our findings are consistent with cross-national research showing that couples in countries with greater female labor force participation and egalitarian gender ideologies report shared management of household tasks as opposed to unilateral decision making (Treas and Tai 2012). 
Thus, those who choose to cohabit indefinitely may have a stronger commitment to gender equality (Blakemore et al. 2005; Präg et al. 2019).

Does declining gender inequality lead to more couples keeping their money separate? Although the data analyzed in this study are cross-sectional and thus unable to address causation, the findings suggest if this is the case, it results from an increase in cohabitation, rather than an increase in the practice of keeping money separate within marriage. That is, married couples are not more likely to keep their money separate in national contexts with less gender inequality. If, as it appears here, money in cohabiting couples' partnerships are governed by different cultural logics than those called upon within marriage - as is implied by the divergent patterns with regard to national gender inequality - then cohabitation looks less like a weaker form of marriage and more like an alternative family arrangement. If marriage is a tradition-bound institution, the practice of cohabitation may reflect efforts at the individual level to mitigate its patriarchal aspects, while taking advantage of the personal, economic, and social benefits afforded by couple relationships. 


\section{Appendix}

Appendix Table A. Income Organization Arrangements by Nation

\begin{tabular}{llcccccccc} 
& \multicolumn{1}{c}{ Total } & \multicolumn{1}{c}{ One $\$$ Manager } & \multicolumn{1}{c}{ Manage $\$$ Together } & Keep Some & Separate & Keep All \$ Separate \\
\hline Argentina & $\mathrm{N}$ & $\mathrm{n}$ & $\%$ & $\mathrm{n}$ & $\%$ & $\mathrm{n}$ & $\%$ & $\mathrm{n}$ & $\%$ \\
Australia & 231 & 83 & .36 & 102 & .44 & 22 & .10 & 24 & .10 \\
Chile & 419 & 66 & .16 & 267 & .64 & 52 & .12 & 34 & .08 \\
Czech Republic & 329 & 173 & .53 & 107 & .33 & 28 & .09 & 21 & .06 \\
Finland & 380 & 147 & .28 & 256 & .49 & 100 & .19 & 24 & .05 \\
France & 649 & 26 & .06 & 128 & .34 & 119 & .31 & 112 & .29 \\
Germany & 386 & 48 & .12 & 233 & .60 & 53 & .14 & 52 & .13 \\
Iceland & 388 & 21 & .05 & 266 & .69 & 47 & .12 & 54 & .14 \\
India & 356 & 120 & .34 & 54 & .15 & 85 & .24 & 97 & .27 \\
Ireland & 396 & 56 & .14 & 203 & .51 & 82 & .21 & 55 & .14 \\
Latvia & 313 & 88 & .28 & 119 & .38 & 79 & .25 & 27 & .09 \\
Lithuania & 328 & 80 & .24 & 132 & .40 & 98 & .30 & 18 & .05 \\
Norway & 398 & 20 & .05 & 195 & .49 & 145 & .36 & 38 & .10 \\
Philippines & 606 & 415 & .68 & 153 & .25 & 29 & .05 & 9 & .01 \\
Poland & 271 & 34 & .13 & 190 & .70 & 24 & .09 & 23 & .08 \\
Spain & 917 & 137 & .15 & 645 & .70 & 94 & .10 & 41 & .04 \\
Sweden & 290 & 12 & .04 & 145 & .50 & 100 & .34 & 33 & .11 \\
Switzerland & 411 & 60 & .15 & 232 & .56 & 70 & .17 & 49 & .12 \\
United States & 392 & 117 & .30 & 192 & .49 & 36 & .09 & 47 & .12 \\
Venezuela & 282 & 103 & .37 & 130 & .46 & 29 & .10 & 20 & .07
\end{tabular}


Appendix Table B. Relative Risk Ratios of Income Allocation Organization Arrangement (Excludes Solo-earner couples (N =6,916))

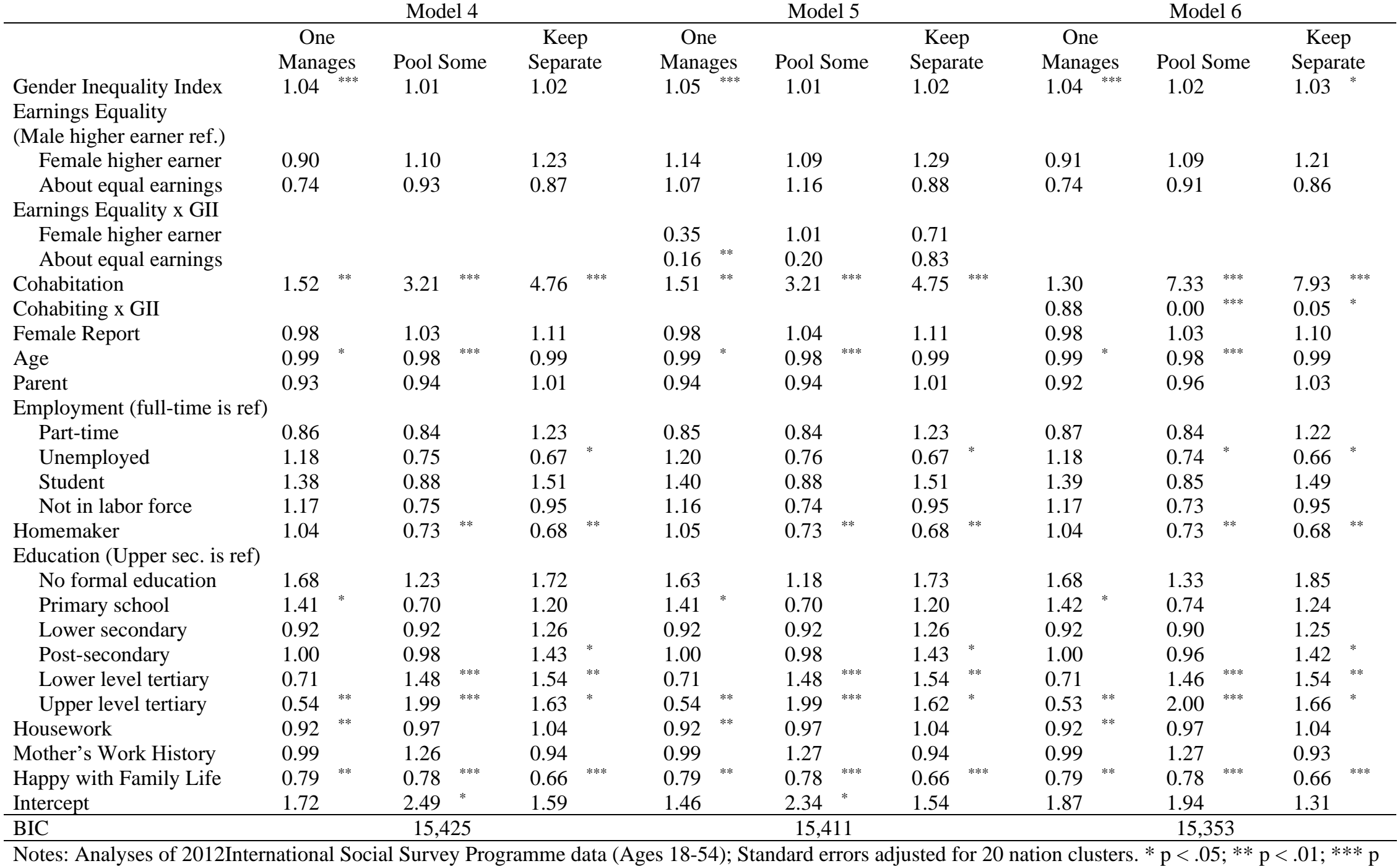

Notes: Analyses of 2012International Social Survey Programme data (Ages 18-54); Standard errors adjusted for 20 nation clusters. $* \mathrm{p}<.05 ; * * \mathrm{p}<.01 ; * * * \mathrm{p}$

$<.001$ (two-tailed test) 
Appendix Table C. Multinomial Regression: Relative Risk Ratios of Income Allocation Organization Arrangement $(\mathrm{N}=7,118)$

\begin{tabular}{|c|c|c|c|c|c|c|c|c|c|}
\hline & \multicolumn{3}{|c|}{ Model 4} & \multicolumn{3}{|c|}{ Model 5} & \multicolumn{3}{|c|}{ Model 6} \\
\hline & $\begin{array}{c}\text { One } \\
\text { Manages }\end{array}$ & $\begin{array}{l}\text { Pool } \\
\text { Some }\end{array}$ & $\begin{array}{c}\text { Keep } \\
\text { Separate }\end{array}$ & $\begin{array}{c}\text { One } \\
\text { Manages }\end{array}$ & $\begin{array}{l}\text { Pool } \\
\text { Some }\end{array}$ & $\begin{array}{c}\text { Keep } \\
\text { Separate }\end{array}$ & $\begin{array}{c}\text { One } \\
\text { Manages }\end{array}$ & $\begin{array}{l}\text { Pool } \\
\text { Some }\end{array}$ & $\begin{array}{c}\text { Keep } \\
\text { Separate }\end{array}$ \\
\hline Gender Inequality Index & $1.04^{* * *}$ & 1.02 & $1.03^{* *}$ & $1.04^{* * *}$ & 1.02 & $1.04^{* *}$ & $1.04^{* * *}$ & $1.03^{* *}$ & $1.04^{* *}$ \\
\hline \multicolumn{10}{|l|}{$\begin{array}{l}\text { Earnings Equality } \\
\text { (Male higher earner ref.) }\end{array}$} \\
\hline Female higher earner & 0.96 & 1.12 & 1.17 & 1.14 & 1.20 & 1.45 & 0.96 & 1.12 & 1.17 \\
\hline About equal earnings & $0.68^{*}$ & 0.96 & 0.93 & 1.05 & 1.38 & 1.08 & 0.67 & 0.96 & 0.93 \\
\hline \multicolumn{10}{|l|}{ Earnings Equality x GII } \\
\hline Female higher earner & & & & 0.99 & 0.99 & 0.99 & & & \\
\hline About equal earnings & & & & $0.97^{*}$ & 0.97 & 0.99 & & & \\
\hline Cohabitation & $1.65^{* *}$ & $3.09^{* * *}$ & $4.27^{* * *}$ & $1.65^{* *}$ & $3.09^{* * *}$ & $4.25^{* * *}$ & $1.38^{*}$ & $7.19^{* * *}$ & $7.80^{* * *}$ \\
\hline Cohabiting x GII & & & & & & & 1.00 & $0.94^{* * *}$ & 0.96 \\
\hline Duration & $1.39^{*}$ & 1.40 & $1.70^{* *}$ & $1.38^{*}$ & 1.39 & $1.70^{* *}$ & $1.44^{*}$ & 1.34 & $1.60^{*}$ \\
\hline
\end{tabular}

Notes: Baseline category is Manage Money Together; Analyses of International Social Survey Programme 2012 (Ages 18-54). Analyses exclude U.S. and Philippines respondents, who do not have collect "duration" data. Models include all control variables but are not shown for space reasons. Standard errors adjusted for 20 nation clusters.

$* \mathrm{p}<.05 ; * * \mathrm{p}<.01 ; * * * \mathrm{p}<.001$ (two-tailed test) 


\section{References}

Addo, F. R., \& Sassler, S. (2010). Financial arrangements and relationship quality in low-income couples. Family Relations, 59(4), 408-423. https://doi.org/10.1111/j.17413729.2010.00612.x

Altintas, E., \& Sullivan, O. (2016). Fifty years of change updated: Cross-national gender convergence in housework. Demographic Research, 35(16), 455-470. https://doi.org/10.4054/DemRes.2016.35.16

Barlow, A. (2008). Cohabiting relationships, money and property: The legal backdrop. The Journal of Socio-Economics, 37(2), 502-518. https://doi.org/10.1016/j.socec.2006.12.037

Bellah, R. N., Madsen, R., Sullivan, W. M., Swidler, A., \& Tipton, S. M. (2008). Habits of the heart: Individualism and commitment in American life. University of California Press.

Bennett, F. (2013). Researching within-household distribution: Overview, developments, debates, and methodological challenges. Journal of Marriage and Family, 75(3), 582597. https://doi.org/10.1111/jomf.12020

Bisdee, D., Daly, T., \& Price, D. (2013). Behind closed doors: older couples and the gendered management of household money. Social Policy and Society, 12(01), 163-174. https://doi.org/10.1017/S147474641200053X

Blakemore, J. E. O., Lawton, C. A., \& Vartanian, L. R. (2005). I can't wait to get married: gender differences in drive to marry. Sex Roles, 53(5-6), 327-335. https://doi.org/10.1007/s11199-005-6756-1

Bolzendahl, C. I., \& Myers, D. J. (2004). Feminist attitudes and support for gender equality: opinion change in women and men, 1974-1998. Social Forces, 83(2), 759-789. https://doi.org/10.1353/sof.2005.0005 
Burgoyne, C. B. (1990). Money in marriage: How patterns of allocation both reflect and conceal power. The Sociological Review, 38(4), 634-665. https://doi.org/10.1111/1467954X.ep5476701

Burgoyne, C. B., \& Lewis, A. (1994). Distributive justice in marriage: Equality or equity? Journal of Community \& Applied Social Psychology, 4(2), 101-114. https://doi.org/10.1002/casp.2450040204

Burgoyne, C. B., \& Morison, V. (1997). Money in remarriage: Keeping things simple - and separate. The Sociological Review, 45(3), 363-395. https://doi.org/10.1111/1467954X.00069

Ciabattari, T. (2001). Changes in men's conservative gender ideologies: Cohort and period influences. Gender \& Society, 15(4), 574-591. https://doi.org/10.1177/089124301015004005

Davis, N. J., \& Robinson, R. V. (1991). Men's and women's consciousness of gender inequality: Austria, West Germany, Great Britain, and the United States. American Sociological Review, 56(1), 72-84. https://doi.org/10.2307/2095674

Elizabeth, V. (2001). Managing money, managing coupledom: A critical examination of cohabitants' money management practices. The Sociological Review, 49(3), 389-411. https://doi.org/10.1111/1467-954X.00338

Gaye, A., Klugman, J., Kovacevic, M., Twigg, S., \& Zambrano, E. (2010). Measuring key disparities in human development: The gender inequality index. United Nations Development Programme Human Development Reports, 41. 
Goldscheider, F., Bernhardt, E., \& Lappegård, T. (2015). The gender revolution: A framework for understanding changing family and demographic behavior. Population and Development Review, 41(2), 207-239. https://doi.org/10.1111/j.1728-4457.2015.00045.x

Hamplová, D., \& Le Bourdais, C. (2009). One pot or two pot strategies? Income pooling in married and unmarried households in comparative perspective. Journal of Comparative Family Studies, 40(3), 355-385.

Hamplová, D., Le Bourdais, C., \& Lapierre-Adamcyk, É. (2014). Is the cohabitation-marriage gap in money pooling universal? Journal of Marriage and Family, 76(5), 983-997. https://doi.org/10.1111/jomf.12138

Heimdal, K. R., \& Houseknecht, S. K. (2003). Cohabiting and married couples' income organization: Approaches in Sweden and the United States. Journal of Marriage and Family, 65(3), 525-538. https://doi.org/10.1111/j.1741-3737.2003.00525.x

Hiekel, N., Liefbroer, A. C., \& Poortman, A.-R. (2014). Income pooling strategies among cohabiting and married couples: A comparative perspective. Demographic Research, S19(55), 1527-1560. https://doi.org/10.4054/DemRes.2014.30.55

Hobson, B. (1990). No exit, no voice: Women's economic dependency and the welfare state. Acta Sociologica, 33(3), 235-250.

Hu, Y. (2019). What about money? Earnings, household financial organization, and housework. Journal of Marriage and Family, O(0). https://doi.org/10.1111/jomf.12590

ISSP Research Group. (2012). International social survey programme: Family and changing gender roles IV - ISSP 2012. doi: 10.4232/1.12022 
Kenney, C. T. (2004). Cohabiting couple, filing jointly? resource pooling and u.s. poverty policies. Family Relations, 53(2), 237-247. https://doi.org/10.1111/j.00222445.2004.00014.x

Kenney, C. T. (2006). The power of the purse: Allocative systems and inequality in couple households. Gender \& Society, 20(3), 354-381. https://doi.org/10.1 $177 / 0891243206286742$

Lauer, S., \& Yodanis, C. (2010). The deinstitutionalization of marriage revisited: A new institutional approach to marriage. Journal of Family Theory \& Review, 2(1), 58-72. https://doi.org/10.1111/j.1756-2589.2010.00039.x

Lewis, S., \& Den Dulk, L. (2008). Parents' experiences of flexible work arrangements in changing European workplaces: A multi-layer contextual approach. Sociological Problems, 5-28.

Ludwig-Mayerhofer, W., Allmendinger, J., Hirseland, A., \& Schneider, W. (2011). The power of money in dual-earner couples: A comparative study. Acta Sociologica, 54(4), 367-383. https://doi.org/10.1177/0001699311422091

Lyngstad, T. H., Noack, T., \& Tufte, P. A. (2011). Pooling of economic resources: A comparison of norwegian married and cohabiting couples. European Sociological Review, 27(5), 624-635. https://doi.org/10.1093/esr/jcq028

Malik, K. (2013). The rise of the South: Human progress in a diverse world. United Nations Development Programm. http://hdr.undp.org/sites/default/files/reports/14/hdr2013_en_complete.pdf 
Noack, T. (2001). Cohabitation in Norway: An accepted and gradually more regulated way of living. International Journal of Law, Policy and the Family, 15(1), 102-117. https://doi.org/10.1093/lawfam/15.1.102

Nyman, C. (1999). Gender equality in 'the most equal country in the world'? Money and marriage in Sweden. The Sociological Review, 47(4), 766-793. https://doi.org/10.1111/1467-954X.00195

Ollier-Malaterre, A., Sarkisian, N., Stawiski, S., \& Hannum, K. M. (2013). Work-life balance and performance across countries: Cultural and Institutional Approaches. In D. Major \& R. Burke (Eds.), Handbook of worklife integration of professionals: Challenges and opportunities (pp. 357-380). Edward Elgar.

Pahl, J. (1990). Household spending, personal spending, and the control of money in marriage. Sociology, 24(1), 119-138.

Permanyer, I. (2013). A critical assessment of the UNDP's Gender Inequality Index. Feminist Economics, 19(2), 1-32. https://doi.org/10.1080/13545701.2013.769687

Präg, P., Begall, K., \& Treas, J. (2019). Understanding the marriage-cohabitation gap in income pooling: Evidence from 29 European countries. https://doi.org/10.31235/osf.io/rqzj3

Roman, C., \& Vogler, C. (1999). Managing money in British and Swedish households. European Societies, 1(3), 419-456. https://doi.org/10.1080/14616696.1999.10749939

Sani, G. M. D. (2015). Within-couple inequality in earnings and the relative motherhood penalty. a cross-national study of European Countries. European Sociological Review, 31(6), 667-682. https://doi.org/10.1093/esr/jcv066

Singh, S., \& Lindsay, J. (1996). Money in heterosexual relationships. Journal of Sociology, 32(3), 57-69. https://doi.org/10.1177/144078339603200304 
Steuber, K. R., \& Paik, A. (2014). Of money and love: Joint banking, relationship quality, and cohabitation. Journal of Family Issues, 35(9), 1154-1176. https://doi.org/10.1177/0192513X13503324

Tichenor, V. J. (1999). Status and income as gendered resources: The case of marital power. Journal of Marriage and Family, 61(3), 638-650. https://doi.org/10.2307/353566

Treas, J. (1993). Money in the bank: Transaction costs and the economic organization of marriage. American Sociological Review, 58(5), 723-734. https://doi.org/10.2307/2096283

Treas, J., \& Tai, T. (2012). How couples manage the household work and power in crossnational perspective. Journal of Family Issues, 33(8), 1088-1116. https://doi.org/10.1177/0192513X11426700

Vitali, A., \& Arpino, B. (2016). Who brings home the bacon? The influence of context on partners' contributions to the household income. Demographic Research, 35(41), 12131244. https://doi.org/10.4054/DemRes.2016.35.41

Vogler, C. (1998). Money in the household: Some underlying issues of power. The Sociological Review, 46(4), 687-713. https://doi.org/10.1111/1467-954X.00136

Vogler, C. (2005). Cohabiting couples: Rethinking money in the household at the beginning of the twenty first century. The Sociological Review, 53(1), 1-29. https://doi.org/10.1111/j.1467-954X.2005.00501.x

Vogler, C., Brockmann, M., \& Wiggins, R. D. (2006). Intimate relationships and changing patterns of money management at the beginning of the twenty-first century. The British Journal of Sociology, 57(3), 455-482. https://doi.org/10.1111/j.1468-4446.2006.00120.x 
Vogler, C., \& Pahl, J. (1993). Social and economic change and the organization of money within marriage. Work, Employment, and Society, 7, 71-95.

Vogler, C., \& Pahl, J. (1994). Money, power and inequality within marriage. The Sociological Review, 42(2), 263-288. https://doi.org/10.1111/1467-954X.ep9407143246

Yodanis, C., \& Lauer, S. (2007a). Economic inequality in and outside of marriage: Individual resources and institutional context. European Sociological Review, 23(5), 573-583. https://doi.org/10.1093/esr/jcm021

Yodanis, C., \& Lauer, S. (2007b). Managing money in marriage: Multilevel and cross-national effects of the breadwinner role. Journal of Marriage and Family, 69(5), 1307-1325.

Yodanis, C., \& Lauer, S. (2014). Is marriage individualized? What couples actually do. Journal of Family Theory \& Review, 6(2), 184-197. https://doi.org/10.1111/jftr.12038

Yu, W. (2015). Placing families in context: Challenges for cross-national family research. Journal of Marriage and Family, 77(1), 23-39. https://doi.org/10.1111/jomf.12152 


\section{Tables}

Table 1. Key Independent Variables by Nation

\begin{tabular}{|c|c|c|c|c|c|c|c|}
\hline \multirow[b]{2}{*}{ Country } & \multicolumn{7}{|c|}{ Earnings Equality } \\
\hline & $\begin{array}{c}\text { Country } \\
\text { Code }\end{array}$ & $\begin{array}{c}\text { Gender } \\
\text { Inequality } \\
\text { Index } \\
\end{array}$ & $\begin{array}{c}\text { Man } \\
\text { Primary- } \\
\text { Earner }\end{array}$ & $\begin{array}{c}\text { Woman } \\
\text { Primary- } \\
\text { Earner }\end{array}$ & $\begin{array}{c}\text { About } \\
\text { Equal } \\
\text { Earners }\end{array}$ & Cohabiting & $\mathrm{N}$ \\
\hline India & IN & 61.0 & .66 & .26 & .08 & .16 & 356 \\
\hline Venezuela & VE & 46.6 & .60 & .19 & .21 & .08 & 282 \\
\hline Philippines & $\mathrm{PH}$ & 41.8 & .77 & .15 & .08 & .17 & 606 \\
\hline Argentina & AR & 38.0 & .71 & .16 & .13 & .36 & 231 \\
\hline Chile & CL & 36.0 & .72 & .13 & .15 & .30 & 329 \\
\hline United States & US & 25.6 & .70 & .23 & .07 & .20 & 392 \\
\hline Latvia & LV & 21.6 & .62 & .21 & .17 & .15 & 313 \\
\hline Lithuania & $\mathrm{LT}$ & 15.7 & .64 & .11 & .25 & .05 & 328 \\
\hline Poland & PL & 14.0 & .70 & .13 & .16 & .07 & 271 \\
\hline Czech Republic & $\mathrm{CZ}$ & 12.2 & .69 & .07 & .23 & .15 & 527 \\
\hline Ireland & IE & 12.1 & .59 & .25 & .15 & .07 & 396 \\
\hline Australia & AU & 11.5 & .70 & .15 & .15 & .18 & 419 \\
\hline Spain & $\mathrm{ES}$ & 10.3 & .64 & .18 & .18 & .10 & 917 \\
\hline Iceland & IS & 8.9 & .70 & .15 & .15 & .05 & 388 \\
\hline France & FR & 8.3 & .62 & .17 & .21 & .19 & 649 \\
\hline Finland & FI & 7.5 & .59 & .18 & .22 & .29 & 380 \\
\hline Germany & $\mathrm{DE}$ & 7.5 & .72 & .18 & .10 & .19 & 386 \\
\hline Norway & $\mathrm{NO}$ & 6.5 & .67 & .16 & .17 & .23 & 398 \\
\hline Switzerland & $\mathrm{CH}$ & 5.7 & .67 & .24 & .09 & .17 & 411 \\
\hline Sweden & $\mathrm{SE}$ & 5.5 & .66 & .20 & .14 & .29 & 290 \\
\hline All & & 18.5 & .67 & .17 & .16 & .17 & 8,269 \\
\hline
\end{tabular}

Note: Countries are in order of most gender inequality to least gender inequality 
Table 2. Description Statistics of Individual-Level Predictors $(\mathrm{N}=8,269)$

\begin{tabular}{llrr} 
Variable & & Means & S.D. \\
\hline Female Report & .57 & \\
Age & & 40.03 & 8.64 \\
Parent & & .72 & \\
Employment & & & \\
& Full-time & .61 & \\
& Part-time & .14 & \\
& Unemployed & .07 & \\
& Student & .02 & \\
& Not in labor force & .16 & \\
Homemaker & & .55 & \\
Education & & & \\
& No formal education & .03 & \\
& Primary school & .04 & \\
& Lower secondary & .18 & \\
& Upper secondary & .25 & \\
& Post secondary & .17 & \\
& Lower level tertiary & .17 & \\
& Upper level tertiary & .17 & \\
Housework & & 4.13 & 2.25 \\
R's Mother Employed & .65 & \\
Happiness with Family Life & 5.75 & 0.98 \\
\hline
\end{tabular}

Note: All variables except for age, housework, and happiness are presented as percentages.

Source: ISSP 2012. 
Table 3. Multinomial Regression: Relative Risk Ratios of Income Organization Arrangement $(\mathrm{N}=8,269)$

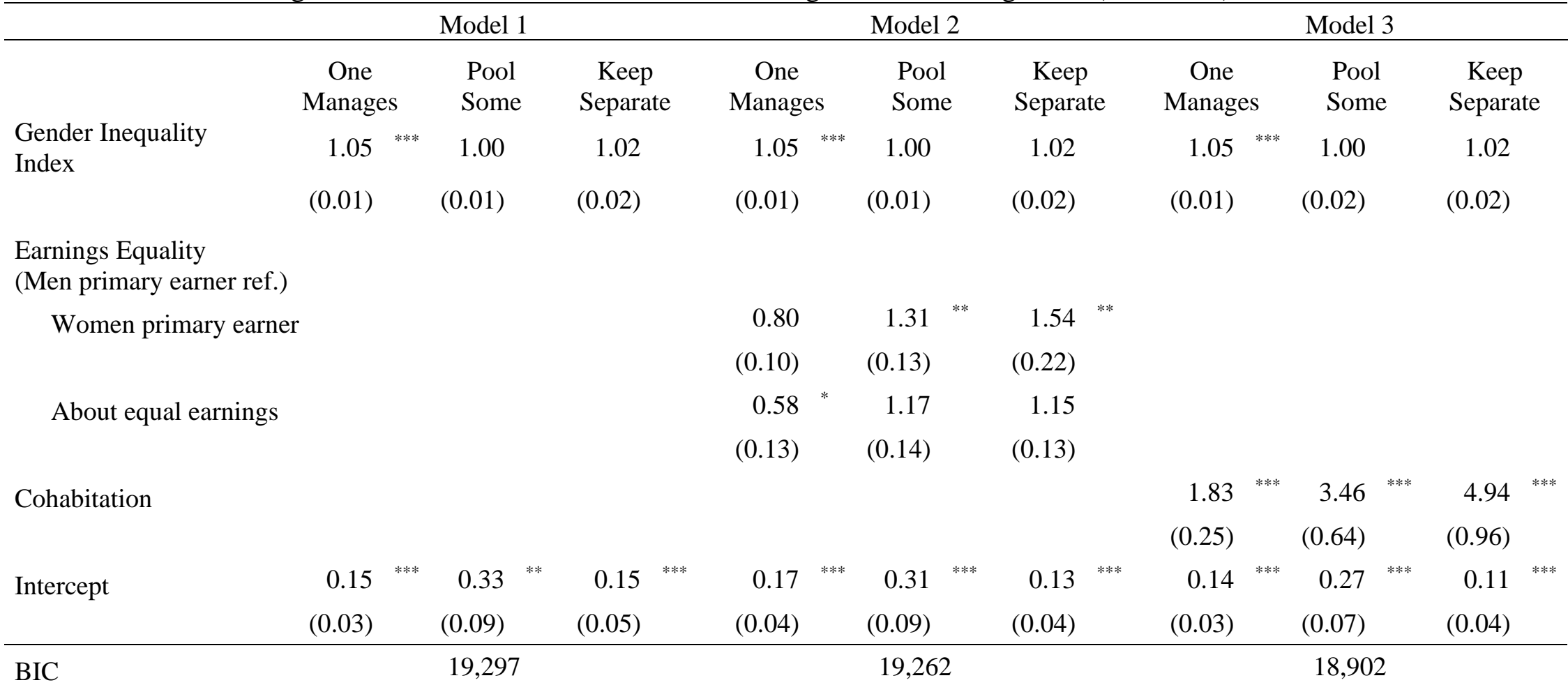

Notes: Baseline category is Manage Money Together; Analyses of International Social Survey Programme 2012 (Ages 18-54). Standard errors adjusted for 20 nation clusters.

$* \mathrm{p}<.05 ; * * \mathrm{p}<.01 ; * * * \mathrm{p}<.001$ (two-tailed test) 
Table 4. Multinomial Regression: Relative Risk Ratios of Income Allocation Organization Arrangement $(\mathrm{N}=8,269)$

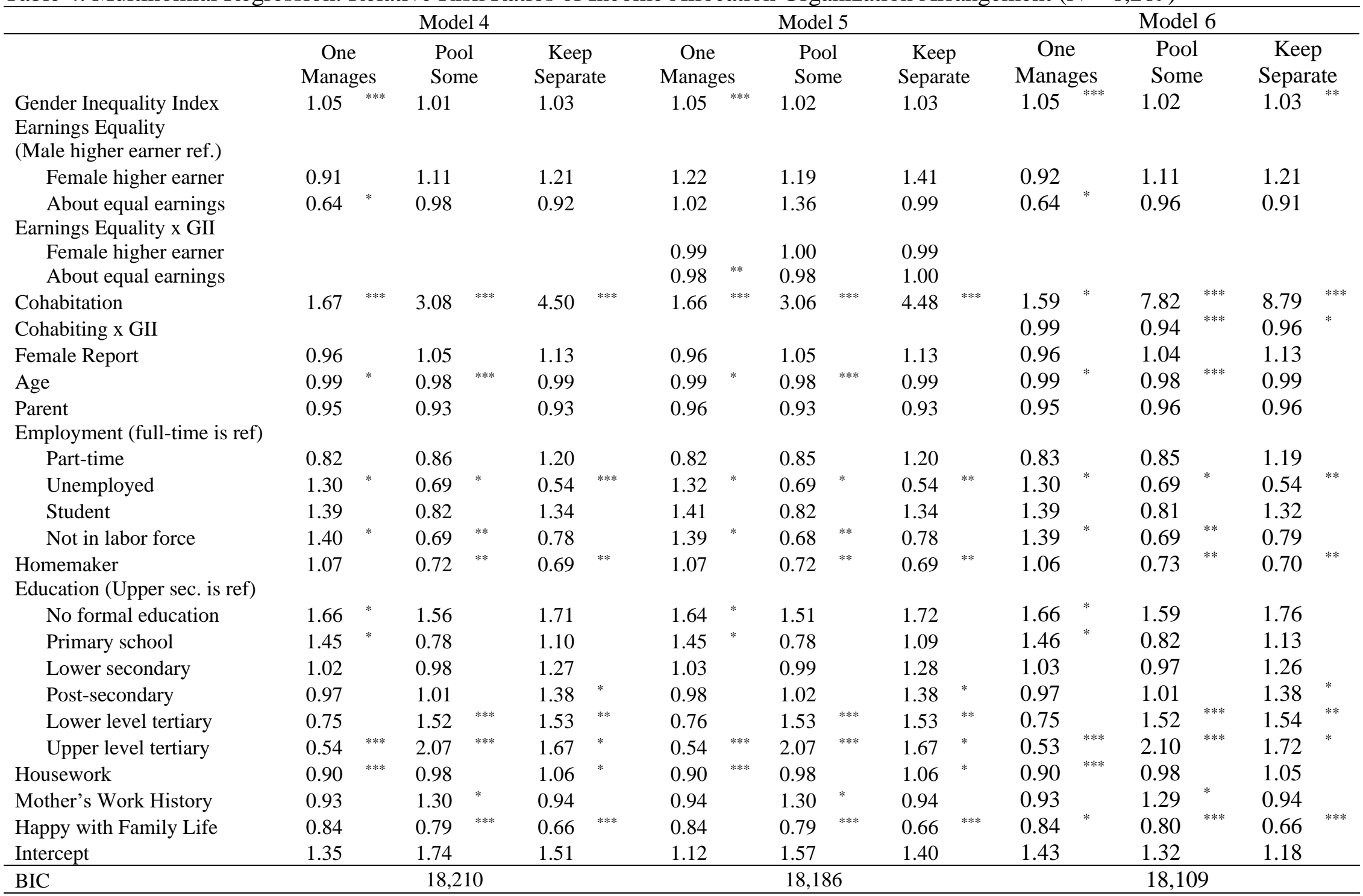

Notes: Baseline category is Manage Money Together; Analyses of International Social Survey Programme 2012 (Ages 18-54). Standard errors adjusted for 20 nation clusters. $* \mathrm{p}<.05 ; * * \mathrm{p}<.01 ; * * * \mathrm{p}<.001$ (two-tailed test) 


\section{Figures}

Figure 1. Proportion of Couples with each Income Organization Approach By Gender Inequality Index

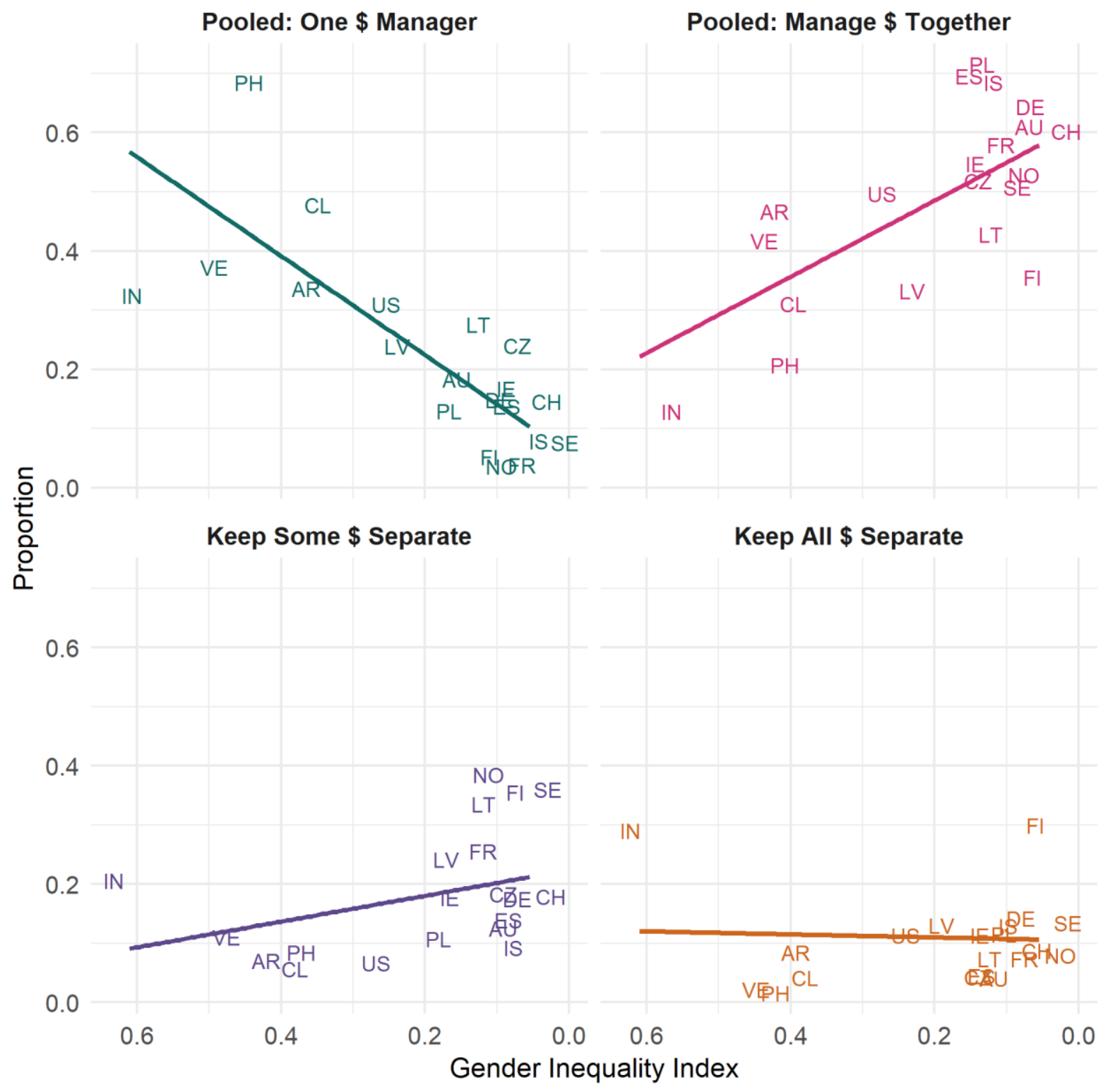

Notes: Higher index scores indicates greater gender inequality. Country abbreviations are listed in Table 1. 
Figure 2. Predicted Probability of Each Organizational Approach

By Couple-level Earnings Equality and Country-level Gender Inequality

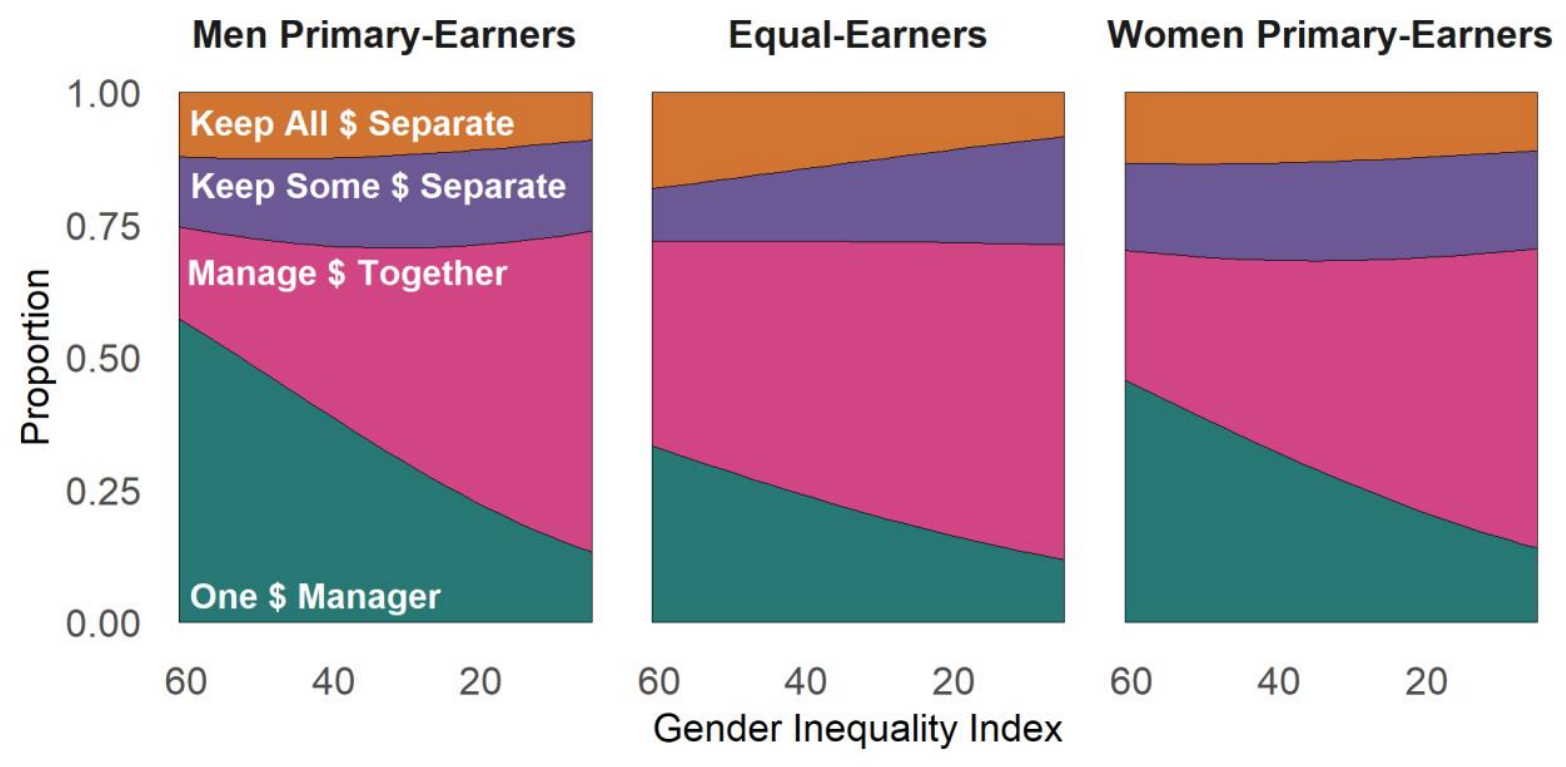

Note: Higher index scores indicates greater gender inequality.

Figure 3. Predicted Probability of Each Organizational Approach By Partnership Status and Country-level Gender Inequality

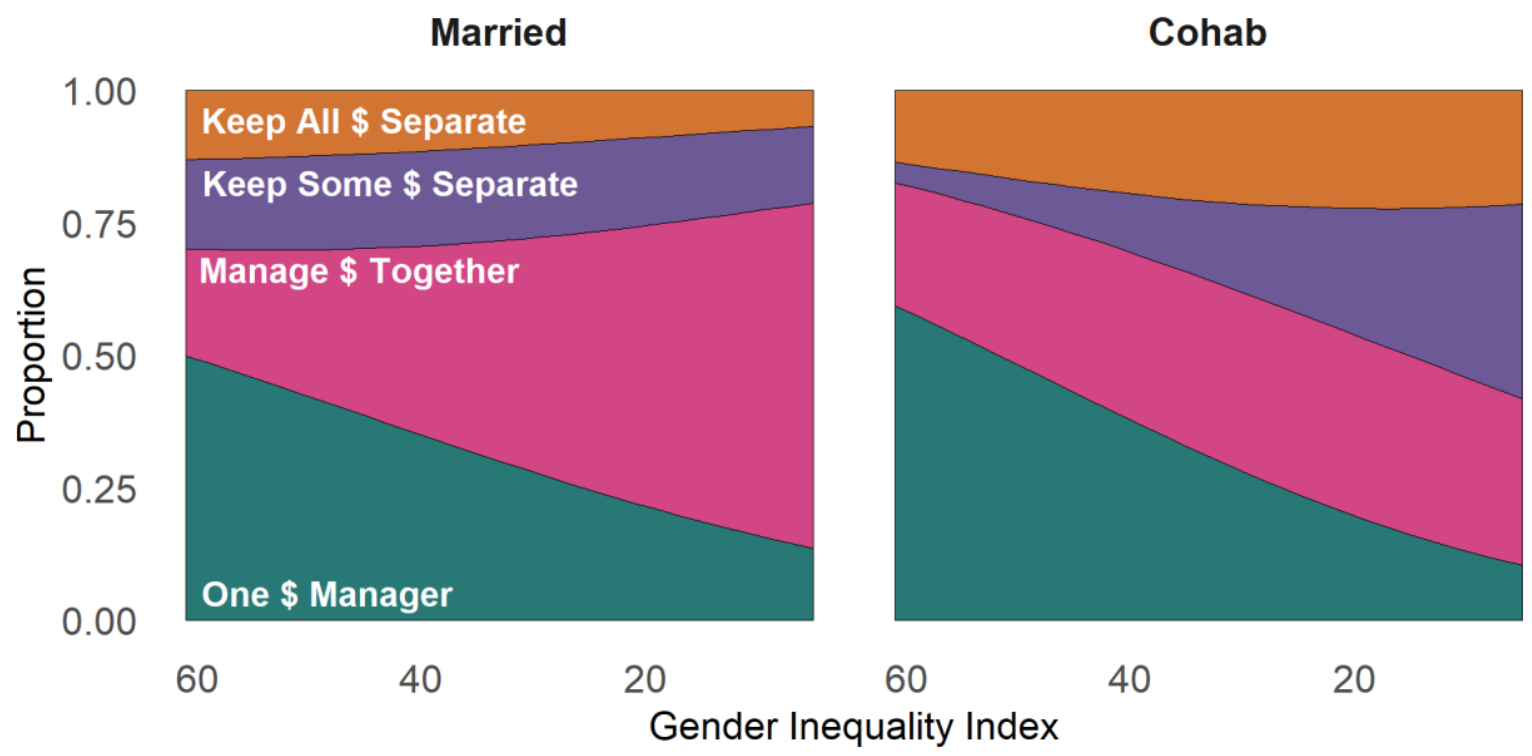

Note: Higher index scores indicates greater gender inequality. 